удК 343.985+316.772.2

\author{
О. П. Ващук
}

\title{
ВИКОРИСТАННЯ НЕВЕРБАЛЬНОЇ ІНФОРМАЦІї У РОЗРОБЦІ МЕТОДИКИ РОЗСЛІДУВАННЯ ОКРЕМИХ КАТЕГОРІЙ ЗЛОЧИНІВ
}

Постановка проблеми. Методика розслідування окремих категорій злочинів синтезує у собі досягнення наукознавчих основ криміналістики, криміналістичної техніки та криміналістичної тактики, утворюючи унікальні типові технології з розслідування окремих категорій злочинів. Такі типові технології (методики) з розслідування окремих категорій злочинів органічно поєднують теоретичні доробки вчених-криміналістів із їх подальшим застосуванням у кримінальному провадженні його учасниками.

Сучасний стан криміналістичної методики розслідування злочинів включає застосування різних підходів, зокрема діяльнісного, функціонального та системного. Враховуючи такий широкий спектр підходів, варто розглянути ще один, так званий інформаційний, для більш ефективного застосування наявних даних, їх перевірки та отримання нових відповідно до злочинної події, що мала місце. Базуючись на інформаційному підході формування криміналістичної методики розслідування злочинів, можна виокремити такі групи їі джерел:

1) теоретичні (наукознавчі основи, криміналістична техніка та криміналістична тактика);

2) практичні (практика розслідування окремих категорій злочинів, опитування і анкетування практичних працівників тощо);

3) статистичні (зафіксовані результати розслідування окремих категорій злочинів у процентному співвідношенні).

Аналіз останніх досліджень і публікацій. Розробка методики розслідування окремих категорій злочинів отримала найбільш завершене викладення у працях таких учених, як О.М. Васильєв, I.О. Возгрін, Ю.П. Гармаєв, О.Ф. Лубін, В.А. Журавель, В.Є. Корноухов, С.Ю. Косарєв, В.В. Тіщенко, С.Н. Чурилов, В.Ю. Шепітько, А.В. Шмонін, Б.В. Щур, I.M. Якимов, а також у працях інших авторів. Звичайно, нині проводяться різноманітні теоретичні дослідження щодо загальних положень методики розслідування окремих категорій злочинів, змісту методики розслідування окремих категорій злочинів та розробки окремих методик із розслідування 
злочинів. Зокрема, в межах цієї статті ми викладаємо результати дослідження щодо використання невербальної інформації у розробці методики розслідування окремих категорій злочинів.

Криміналістика, маючи два об’єкти дослідження - злочинну діяльність (підготовку, вчинення, приховування злочинів) та діяльність із розслідування злочинів, виокремлює центральний елемент дослідження - людину. Сама людина (а точніше ії діяльність) досліджується у двох аспектах:

- діяльність із підготовки, вчинення та приховання злочинних правопорушень;

- діяльність із попередження, виявлення, розслідування та розкриття злочинів.

Маючи на увазі два вказані вище аспекти, можна сформувати концептуальні основи застосування інформації під час розробки методик розслідування окремих категорій злочинів. Зосередимо наше дослідження на інформаційному складнику, що, у свою чергу, містить нормативно-правові акти, криміналістично-значущу інформацію, криміналістичні рекомендації та правила. Далі криміналістично значущу інформацію звузимо до невербального складника людської комунікації та навколишньої обстановки. Слід підкреслити, що дослідження невербальних засобів неможливе без їх вербального осмислення та роз'яснення.

Метою статті є з'ясування питань щодо використання невербальної інформації у розробці методики розслідування окремих категорій злочинів.

Виклад основного матеріалу дослідження. Основою розуміння системи криміналістики вважаємо позицію В.В. Тіщенка з урахуванням iii історії розвитку та сучасного стану [22, с. 230-238]. Викладені вченим наукові засади розробки криміналістичних методик розслідування сформовані у таких напрямах:

1) принципи наукової розробки методики розслідування окремих категорій злочинів:

- розгляд об'єктів методики розслідування з урахуванням системно-діяльнісного і функціонального підходів;

- використання даних і досягнень інших наук;

- розробка методичних рекомендацій на основі криміналістичного аналізу та створення криміналістичної характеристики;

- використання досвіду слідчої практики;

- розробка методичних рекомендацій на основі криміналістичної класифікації злочинів;

- розробка окремих методик розслідування на основі обставин виду злочину, що підлягають встановленню;

- розробка напрямів і завдань розслідування відповідно до специфіки етапів розслідування;

- розробка методичних рекомендацій на основі інформаційно-ситуаційної оцінки стану розслідування;

- виокремлення типових завдань та програми їх вирішення з урахуванням категорії злочинів; 
О. П. Ващцк. Використання невербальної інформації у розробці методики розслідування... 79

- виокремлення специфічних тактичних і технічних прийомів під час проведення слідчих дій;

2) принципи побудови методики розслідування злочину у практичній діяльності слідчого:

- вибір напряму розслідування із досягненням кінцевої мети;

- визначення сутності подіі;

- використання у розслідуванні даних криміналістичної характеристики відповідної категорії злочинів;

- застосування ситуативного підходу до постановки тактичних завдань і засобів їх вирішення;

- етапність методики розслідування;

- планомірність ходу розслідування;

- використання у діяльності з розкриття злочинів різних форм і методів взаємодіі;

- застосування сучасних наукових i технічних можливостей [23, с. 19-22].

Окремі важливі акценти на формуванні методик розслідування злочинів містяться у працях Л.Я. Драпкіна та В.М. Карогодіна [8], В.А. Журавля [9], у праці колективу авторів щодо теоретичних та практичних проблем забезпечення ефективності досудового провадження [21, с. 106-158]. I.В. Гловюк розкрила окремі аспекти визначення моделі розслідування у процедурі Міжнародного кримінального суду [7, с. 180-183]. Попри надзвичайний інтерес дослідників до проблематики криміналістичної методики, ми дотримуємося думки, що найбільш вдпалою є структура теоретичних основ криміналістичної методики розслідування злочинів, запропонована В.В. Тіщенком. У своїх працях щодо проблем і тенденцій розвитку криміналістичної методики розслідування злочинів до теоретичних основ криміналістичної методики розслідування В.В. Тіщенко включає:

- визначення предмета, завдань, змісту криміналістичної методики;

- встановлення джерел формування і розгляд методологічних підходів;

- криміналістичний аналіз злочинної діяльності та діяльності з їі розслідування;

- класифікацію методик розслідування;

- принципи розробки і застосування окремих методик;

- загальні положення організації і планування розслідування;

- методику побудови програм і алгоритмів розслідування злочинів [18, с. 362-369].

Підтримуючи думку В.В. Тіщенка щодо поділу змісту криміналістичної методики розслідування на дві частини (як загальних положень та окремих методик розслідування конкретних категорій злочинів [19, с. 174]), пропонується зосередити увагу на аналізі сучасного змісту окремих методик розслідування конкретних категорій злочинів. На підставі аналітичного огляду наявних наукових праць із теоретичних основ формування та застосування криміналістичних методик [27], методики розслідування злочинів [25], теоретичних основ формування криміналіс- 
тичних методик розслідування злочинів [6, с. 342], моделі розслідування злочинів і засобів криміналістичної тактики [24, с. 447-455], наукових засад розробки криміналістичних методик розслідування [23, с. 17-22], теоретичних основ методики розслідування злочинів [16, с. 90-94], сутності методики розслідування і ії принципів [15, с. 61-64], принципів криміналістичної методики у діяльності з розслідування злочинів [11, с. 214], сучасних наукових концепцій криміналістичних методик [9, с. $304 ; 10$, с. 177-187] як моделей засобів і технологій розкриття злочинів [13, с. 592; 14], проблем методики розслідування окремих видів злочинів та проблеми створення криміналістичних методик розслідування злочинів $[3 ; 5 ; 12 ; 17 ; 20]$ нами розроблено власне бачення структури і змісту методики розслідування окремих категорій злочинів. Варто також відзначити, що до теоретичних основ методики розслідування окремих категорій злочинів на сучасному етапі включаються можливості побудови універсальної базової методики [5, с. 56], предмета розслідування [25, с. 238], криміналістичних технологій [14; 1], криміналістичної стратегії [2, с. 203-209].

У науковій праці щодо сучасного стану і перспектив розвитку криміналістичної методики розслідування В.В. Тіщенко включає до структури окремих методик розслідування такі елементи:

- криміналістичний аналіз;

- обставини, які підлягають встановленню;

- аналіз та оцінку вихідних ситуацій на перевірочному етапі розслідування;

- типові слідчі ситуації, типові версії, завдання і засоби їх перевірки на перевірочному і початковому етапах розслідування;

- слідчі ситуації, завдання і програми ї вирішення на подальшому i заключному етапах розслідування;

- тактичні й організаційні особливості проведення слідчих дій і тактичних операцій [19, с. 175].

Учений підкреслює (і з цим варто погодитися), що кожен із названих ним елементів у кожній конкретній методиці розслідування деталізується і наповнюється відповідним змістом. Однак, усвідомлюючи глибину порушених питань, доцільно відобразити структуру методики розслідування окремих категорій злочинів у такому вигляді.

1. Криміналістичний аналіз злочину:

- криміналістична характеристика;

- криміналістична класифікація;

- обставини, що підлягають встановленню.

2. Початковий етап розслідування злочину:

- типові слідчі ситуації;

- типові версії;

- напрями та завдання розслідування;

- засоби розслідування (слідчі (розшукові) дії та негласні слідчі (розшукові) діі). 
3. Подальший етап розслідування злочину:

- типові слідчі ситуації;

- типові версіі;

- напрями та завдання розслідування;

- засоби розслідування (слідчі (розшукові) дії та негласні слідчі (розшукові) дії).

4. Заключний етап розслідування злочинів:

- типові слідчі ситуації;

- типові версії;

- напрями та завдання розслідування;

- засоби розслідування (слідчі (розшукові) дії та негласні слідчі (розшукові) діі).

Розглянута структура методики розслідування окремих категорій злочинів $є$ типовою технологією розслідування у широкому значенні з урахуванням більшості важливих елементів кримінального провадження. Якщо говорити про вузьке значення змісту методики розслідування окремих категорій злочинів, то варто зупинитися на загальних положеннях злочину та розслідуванні злочинів у такому вигляді:

1) криміналістичний аналіз злочину:

- криміналістична характеристика

- криміналістична класифікація;

- обставини, що підлягають встановленню;

2) розслідування злочину:

- типові слідчі ситуації;

- типові версії;

- напрями та завдання розслідування;

- засоби розслідування (слідчі (розшукові) дії та негласні слідчі (розшукові) дії).

Дослідники на власний розсуд вирішують те, якою створювати методику розслідування окремої категорії злочину: повною чи скороченою, у широкому значенні чи вузькому з урахуванням таких чинників:

1) категорія злочину та їі склад;

2) досвід практики кримінальних проваджень;

3) статистика розслідування;

4) наявні проблеми та особливості під час розслідування на початковій чи подальшій стадії розслідування злочинів.

3 огляду на вищеозначене варто підкреслити, що проблематикою змісту методики розслідування окремих категорій злочинів займаються багато вчених, а сфери питань виходять далеко за межі традиційної криміналістики. Тому доречним і логічним буде розгляд у цьому напрямі можливостей невербальної інформації під час побудови методик розслідування окремих категорій злочинів і подальшого їх практичного застосування під час розслідування злочинів. Нині є великий попит із боку практичних працівників (слідчі, прокурори, оперативники, судді та ін.) на можливості використання цих знань у їхній професійній діяльності. 
Невербальна інформація, будучи невід'ємною складовою частиною криміналістично значущої інформації, відіграє орієнтуючу роль як на досудовому розслідуванні, так і у судовому провадженні. У рамках дослідження криміналістично значущої інформації із паралельним зосередженням як на вербальному, так і на невербальному складнику, є можливість отримати дані не тільки про зовнішній образ будь-якого учасника кримінального провадження, а й про його внутрішній світ, що сприяє орієнтуванню стосовно емоційного стану учасника кримінального провадження щодо події, яка мала місце в минулому. Таким чином, має місце створення окремої системи даних особистого характеру, що складається із психофізіологічних та інших властивостей суб'єктів кримінального провадження.

Органічне використання невербальної інформації полягає у його гармонічному поєднанні з іншими видами комунікації у кожному елементі методики розслідування окремих категорій злочинів. Можливо, пошуки ідеальної форми поєднання використання невербальної і вербальної інформації не призведуть до ефективного результату у зв'язку з індивідуальними особливостями кожного учасника кримінального провадження. Однак створення типових рекомендацій використання невербальної інформації у побудові методики розслідування окремих категорій злочинів призведе до ефективного наповнення криміналістично значущою інформацією.

Важливим також $є$ поєднання теорії і практики використання невербальної інформації у методиці розслідування окремих категорій злочинів. Слід мати на увазі, що теоретичні розробки використання невербальної інформації повинні знаходити своє застосування у практиці розслідування. Зазначимо, що кожен індивід має навички у сприйнятті невербальної інформації, яка його оточує із моменту народження та супроводжує протягом усього життєвого циклу. Тому ми намагаємося дослідити і розкрити ті невербальні засоби, надаючи їм власне тлумачення та намагаючись роз'яснити напрями їх застосування.

Злочин і наслідки, які він спричиняє, специфічні, тому й невербальна інформація, що має тут місце, теж має свої особливості. Саме тому необхідно надавати рекомендації щодо іiі тлумачення і використання усім зацікавленим сторонам кримінального провадження. Адже, маючи об'єктом дослідження конкретну кримінально-релевантну подію, необхідно враховувати ці особливості, які, у свою чергу, теж набувають спеціфічного характеру під час їх практичного застосування. У результаті маємо точки накладання двох різних складників як звичну (буденну) поведінку і ситуацію, визначену Кримінальним процесуальним кодексом.

Отже, методика розслідування окремих категорій злочинів повинна розроблюватись із врахуванням досліджень у сфері невербальної інформації, a саме:

1) криміналістичний аналіз злочину:

- криміналістична характеристика повинна формуватись із врахуванням психофізіологічної діагностики учасників кримінального провадження та обстановки події кримінального провадження; 
- криміналістична класифікація (класифікація учасників кримінального провадження з урахуванням психофізіологічної діагностики, класифікація інших елементів криміналістичної характеристики з урахуванням психофізіологічного складника);

- обставини, що підлягають встановленню (урахування психофізіологічного складника під час їх встановлення та описування);

2) початковий етап розслідування злочину (врахування психофізіологічного складника індивіда та врахування невербальних характеристик інших елементів криміналістичної характеристики):

- типові слідчі ситуації;

- типові версіі;

- напрями та завдання розслідування;

- засоби розслідування (слідчі (розшукові) дії та негласні слідчі (розшукові) діі);

3) подальший етап розслідування злочину (врахування психофізіологічного складника індивіда та врахування невербальних характеристик інших елементів криміналістичної характеристики):

- типові слідчі ситуації;

- типові версіі;

- напрями та завдання розслідування;

- засоби розслідування (слідчі (розшукові) дії та негласні слідчі (розшукові) діі);

4) заключний етап розслідування злочинів (урахування психофізіологічного складника індивіда та врахування невербальних характеристик інших елементів криміналістичної характеристики):

- типові слідчі ситуації;

- типові версії;

- напрями та завдання розслідування;

- засоби розслідування (слідчі (розшукові) дії та негласні слідчі (розшукові) діі).

Висновки. Таким чином, невербальна інформація у формі психофізіологічного діагностування індивіда та врахування невербальних характеристик інших елементів криміналістичної характеристики, на нашу думку, дозволить суттєво підвищити ефективність застосування криміналістичних рекомендацій у межах кримінального провадження, а також під час розробки методик розслідування окремих категорій злочинів.

\section{Література}

1. Барцицька А.А. Криміналістичні технології: сутність та місце в системі криміналістичної науки : автореф. дис. ... канд. юрид. наук : спец. 12.00.09 / А.А. Барцицька ; Нац. ун-т «Одеська юридична академія». - Одеса, 2011. - 19 с.

2. Берназ В.Д. Криминалистическая стратегия в расследовании преступлений / В.Д. Берназ / / Криміналістика XXI століття : матер. Міжнар. наук.-практ. конфер. - Харків, 2010. - С. 203-209.

3. Васильев А.Н. Проблемы методики расследования отдельных видов преступлений / А.Н. Васильев. - М. : Изд-во Моск. ун-та, 1978. - 72 с.

4. Возгрин И.А. Общие положения методики расследования отдельных видов преступлений / И.А. Возгрин. - Львов : ВПУ МВД СССР, 1976. - 55 с. 
5. Гармаев Ю.П. Проблемы создания криминалистических методик расследования преступлений. Теория и практика / Ю.П. Гармаев, А.Ф. Лубин. - Санкт-Петербург, 2006. - С. 56.

6. Гармаев Ю.П. Теоретические основы формирования криминалистических методик расследования преступлений / Ю.П. Гармаев. - Иркутск : ИЮИ ГП РФ, 2003. - 342 с.

7. Гловюк И.В. Некоторые аспекты определения модели расследования в процедуре международного уголовного суда / И.В. Гловюк / / Міжнародні читання, присвячені пам'яті професора Імператорського Новоросійського університету П.Є. Казанського : матер. Міжнар. конфер. (м. Одеса, 22-23 жовтня 2010 р.). - Одеса, 2010. - С. 180-183.

8. Драпкин Л.Я. Криминалистика : [учеб.] / Л.Я. Драпкин, В.Н. Карагодин, Я.М. Злоченко. - 2-е изд. - М. : Проспект, 2011. - 768 с.

9. Журавель В.А. Криміналістичні методики: сучасні наукові концепції : [монографія] / В.А. Журавель. - Харків : Апостіль, 2012. - 304 с.

10. Журавель В.А. Сучасні концепції формування окремих криміналістичних методик розслідування злочинів / В.А. Журавель / / Вісник Академії правових наук України. - 2007. № 2 (49). - C. 177-187.

11. Колодіна А.С. Принципи криміналістичної методики у діяльності з розслідування злочинів : дис. ... канд. юрид. наук : спец. 12.00 .09 / А.С. Колодіна. - Одеса, 2016. - 214 с.

12. Криминалистика. Методика расследования отдельных видов преступлений : [учеб.] / С.А. Голунский, Б.М. Шавер ; под ред. А.Я. Вышинского. - М. : Юрид. изд-во НКЮ СССР, 1939. - 372 с

13. Образцов В.А. Криминалистика : [учеб.] / В.А. Образцова. - М. : Юрид. лит-ра, 1995. - 592 с.

14. Образцов В.А. Криминалистика: модели средств и технологий раскрытия преступлений / В.А. Образцов. - М., 2004. - 397 с.

15. Селиванов Н.А. Сущность методики расследования и ее принципы / Н.А. Селиванов / / Социалистическая законность. - 1976. - № 5. - С. 61-64.

16. Танасевич В.Г. Теоретические основы методики расследования преступлений / В.Г. Танасевич / / Советское государство и право. - 1976. - № 6. - С. 90-94.

17. Тищенко В.В. О видах, форме и содержании криминалистических методик расследования преступлений / В.В. Тищенко / / Правове життя сучасної України : матер. Міжнар. наук. конф. проф.-викл. та аспірант. складу / відп. за вип. В.М. Дрьомін ; НУ ОЮА, Півд. регіон, центр НАПрН України. - Одеса : Фенікс, 2014. - Т. 1. - С. 740-742.

18. Тищенко В.В. Теоретические основы криминалистической методики расследования преступлений: проблемы и тенденции / В.В. Тищенко / / Наукові праці Національного університету «Одеська юридична академія». Т. 10 / голов. ред. С.В. Ківалов. - Одеса : Юрид. літ-ра, 2011. - C. 362-371.

19. Тищенко В.В. Криминалистическая методика расследования преступлений: современное состояние и перспективы развития / В.В. Тищенко / / Наукові праці Національного університету «Одеська юридична академія» : зб. наук. праць / редкол.: С.В. Ківалов (голов. ред.),

В.М. Дрьомін (заст. голов. ред.), Ю.П. Аленін [та ін] ; відп. за вип. В.М. Дрьомін. - Одеса : Юрид. літ-ра, 2010. - Т. 9. - С. 170-181.

20. Тіщенко В.В. Щодо шляхів оптимізації розробки методик розслідування злочинів / В.В. Тіщенко / / Наукові праці Національного університету «Одеська юридична академія» : зб. наук. праць / редкол.: С.В. Ківалов (голов. ред.), В.М. Дрьомін (заст. голов. ред.), Ю.П. Аленін [та ін] ; відп. за вип. В.М. Дрьомін. - Одеса : Юрид. літ-ра, 2014. - Т. 14. - С. 90-96.

21. Тіщенко В.В. Теоретичні та практичні проблеми забезпечення ефективності досудового провадження / В.В. Тіщенко, Ю.П. Аленін, О.П. Ващук, А.В. Мурзановська, О.О. Торбас, Ю.М. Немно, А.О. Панасюк, М.В. Шкрибайло, О.А. Земляна / / Наукові праці Національного університету «Одеська юридична академія» : зб. наук. праць / редкол.: С.В. Ківалов (голов. ред.), М.В. Афанасьєва (заст. голов. ред.), Ю.П. Аленін [та ін] ; відп. за вип. М.В. Афанасьєва. - Одеса : Юрид. літ-ра, 2015. - Т. 17. - С. 106-158.

22. Тищенко В.В. Система кримналистики: история и современное состояние / В.В. Тищенко / / Наукові праці Національного університету «Одеська юридична академія» / голов. ред. С.В. Ківалов. - Одеса : Юрид. літ-ра, 2008. - Т. VII. - С. 230-238.

23. Тіщенко В.В. Наукові засади розробки криміналістичних методик розслідування / В.В. Тіщенко / / Актуальні проблеми держави і права : зб. наук. праць. - Вип. 32. - Одеса : Юрид. літ-ра, 2007. - С. 17-22. 
24. Шепитько В.Ю. Модель расследования преступлений и средства криминалистической тактики / В.Ю. Шепитько / / Наукові праці Національного університету «Одеська юридична академія» : зб. наук. пр. / редкол.: С.В. Ківалов (голов. ред.), В.М. Дрьомін (заст. голов. ред.), Ю.П. Аленін [та ін.] ; відпов. за вип. В.М. Дрьомін. - Одеса : Юрид. літ-ра, 2012. - Т. 11. C. $447-455$.

25. Чурилов С.Н. Криминалистическая методика: история и современность / С.Н. Чурилов. - М. : ИКЦ «Маркетинг», 2002. - 368 с.

26. Шмонин А.В. Методика расследования преступлений / А.В. Шмонин. - М. : Юстицинформ, 2006. - 462 с.

27. Щур Б.В. Теоретичні основи формування та застосування криміналістичних методик : [монографія] / Б.В. Щур. - Харків : Харків юрид., 2010. - 320 с.

\section{А н о т а ц і я}

Ващук О. П. Використання невербальної інформації у розробці методики розслідування окремих категорій злочинів. - Стаття.

Крізь призму усталеної методики розслідування окремих категорій злочинів досліджено можливості використання у ній невербальної інформації. Розглянуто принципи формування методики розслідування окремих категорій злочинів. Наведено класичний зміст методики розслідування окремих категорій злочинів. Розроблено унікальний авторський зміст методики розслідування окремих категорій злочинів та методики розслідування окремих категорій злочинів із використанням невербальної інформації.

Ключові слова: методика розслідування, категорія злочинів, використання, невербальна інформація, принципи, форми, структура.

\section{А н н о т а ци я}

Ващук А. П. Использование невербальной информации в разработке методики расследования отдельных категорий преступлений. - Статья.

Сквозь призму устоявшейся методики расследования отдельных категорий преступлений исследованы возможности использования в ней невербальной информации. Рассмотрены принципы формирования методики расследования отдельных категорий преступлений. Приведено классическое содержание методики расследования отдельных категорий преступлений. Разработано уникальное авторское содержание методики расследования отдельных категорий преступлений и методики расследования отдельных категорий преступлений с использованием невербальной информации.

Ключевые слова: методика расследования, категория преступлений, использование, невербальная информация, принципы, формы, структура.

\section{S u m m a r y}

Vashchuk O. P. Use of non-verbal information in the development of a methodology for investigating certain categories of crimes. - Article.

Prism of the established methodology for investigating certain categories of crimes explored the possibility of using non-verbal information in it. The principles of forming a method of investigation of certain categories of crimes are considered. The classical content of the methodology of investigating certain categories of crimes is given. A unique author's content of the methodology of investigation of certain categories of crimes and methods of investigating certain categories of crimes with the use of non-verbal information was developed.

Key words: investigation technique, crime category, use, nonverbal information, principles, forms, structure. 